\title{
Macromineral requirements by beef cattle under pasture supplementation ${ }^{1}$
}

\author{
Maykel Franklin Lima Sales ${ }^{2}$, Mário Fonseca Paulino ${ }^{3}$, Sebastião de Campos Valadares Filho ${ }^{3}$, \\ Marlos Oliveira Porto ${ }^{4}$, Victor Rezende Moreira Couto ${ }^{4}$, Pedro Veiga Rodrigues Paulino ${ }^{3}$
}

\footnotetext{
${ }^{1}$ Pesquisa parcialmente financiada pelo CNPq e pela FAPEMIG

2 Embrapa Acre, Rio Branco - AC.

${ }^{3}$ Departamento de Zootecnia - UFV, Viçosa - MG.

${ }^{4}$ Pós-graduação em Zootecnia - UFV, Viçosa - MG.
}

ABSTRACT - The objective of this work was to determine macromineral requirements by Zebu steers grazing Brachiaria decumbens supplemented with concentrate. It was used 24 non-castrated steers, at an average age of 7 months and at initial average weight $180 \mathrm{~kg}$. Eight control animals were slaughtered for determining initial body composition. The 16 remaining animals were divided in four four-animal plots, in a complete random design. Each plot received mineral mixture or supplements at the levels $0.75 ; 1.50$ or $2.25 \mathrm{~kg} / \mathrm{animal} /$ day. The right half-carcass of eight animals, two per group, was dissected in muscle, fat and bones and all body constituents were weighted for determination of empty body weight and body composition. Net requirements of calcium and phosphorus for an animal at $400 \mathrm{~kg}$ body weight were $11.13 \mathrm{~g}$ and $5.40 \mathrm{~g}$, respectively. To estimate dietary requirements of maintenance and after, sum them to dietary requirements for gain in order to obtain total dietary requirements, it was adopted endogenous losses and bioavailability present in literature for each mineral macroelement. Total dietary requirement for calcium, phosphorus, magnesium, sodium and potassium for a 400-kg BW animal with 1.0-kg daily weight gain were 34.59; 17.36; 7.82; 5.19 and $41.11 \mathrm{~g} /$ day, respectively. Macromineral requirements by beef cattle under pasture supplementation are similar to those recommended by BR-Corte for beef cattle in feedlots.

Key Words: calcium, nutritional requirement, phosphorus, supplementation, Zebu

\section{Exigências de macrominerais de bovinos de corte sob suplementação a pasto}

RESUMO - Objetivou-se determinar as exigências de macrominerais de novilhos zebuínos em pastagem de Brachiaria decumbens suplementada com concentrado. Foram utilizados 24 novilhos, não-castrados, com idade e pesos médio iniciais de 7 meses e $180 \mathrm{~kg}$. Foram abatidos oito animais-referência para determinação da composição corporal inicial. Os 16 animais restantes foram divididos em quatro lotes de quatro animais, em delineamento inteiramente casualizado. Cada lote recebeu mistura mineral ou suplementos nos níveis de 0,$75 ; 1,50$ ou 2,25 kg/animal/dia. A meia-carcaça direita de oito animais, dois por grupo, foi dissecada em músculo, gordura e ossos e todos os constituintes do corpo foram pesados para determinação do peso de corpo vazio e da composição corporal. As exigências líquidas de cálcio e fósforo para um animal de $400 \mathrm{~kg}$ de peso corporal foram, respectivamente, 11,13 g e 5,40 g. Para estimar as exigências dietéticas de mantença e, posteriormente, somá-las às exigências dietéticas para ganho, no intuito de se obter as exigências dietéticas totais, foram adotadas as perdas endógenas e a biodisponibilidade presentes na literatura para cada macroelemento mineral. As exigências dietéticas totais de cálcio, fósforo, magnesium, sódio e potássio para um animal de $400 \mathrm{~kg}$ de PC com ganho diário de 1,0 kg foram, respectivamente, 34,59; 17,36; 7,82; 5,19 e 41,11 g/dia. As exigências em macrominerais de bovinos de corte sob suplementação a pasto são semelhantes às recomendadas pelo BR-Corte para bovinos de corte em confinamento.

Palavras-chave: cálcio, exigências nutricionais, fósforo, suplementação, zebuínos

\section{Introduction}

Determination of mineral dietary requirements for bovines being raised on pasture conditions is extremely complex due to the several factors that directly or indirectly influence their use by the animals. Among those factors, some are inherent to the food or to the diets, as bioavailability and mineral chemical form in dietary ingredients; other are attributable to the animal, as body weight, variability among breeds, production level and nutritional status 
(ARC, 1980; Conrad etal., 1985; AFRC, 1991; Coelho da Silva, 1995; NRC, 2000).

Besides appropriate supplement of minerals, AFRC (1991) stresses that proper levels of protein and energy are needed for a normal development of the bones. It is listed in NRC (2000) requirements of calcium and phosphorus for protein daily gain and Conrad et al. (1985) stated that appropriate nutrition of these minerals depends on $\mathrm{D}$ vitamin level in the diet.

Despite of representing only $4 \%$ of body weight of the animals, minerals are present in different proportions in all tissues and they exert vital functions in the organism, which are reflected by the performance of the animal (Dayrell, 1993).

Mineral retention depends on the weight gain composition (bones, muscles and fat). Greater fat depositions reduce mineral depositions and, consequently, their requirements by the animals inasmuch as concentration of these inorganic elements in the adipose tissue are lower than in the muscles and in the bones, which contain approximately $99 \%$ and $80 \%$ of body calcium and phosphorus, respectively (NRC, 2000).

Thus, factors that modify gain composition as type of the diet, sex, genetic group, age and weight of the animals, affect mineral composition and net requirement for weight gain (Paulino et al., 1999).

Macromineral nutritional requirements are, in general, estimated by factorial methods (ARC, 1980), which are based in net quantities deposited in the body of the animal, added by the needed quantity to meet endogen secretions, considered net requirement of maintenance. The sum of maintenance fractions and production is the total net requirement that, when corrected by one coefficient of absorption of the inorganic element in the digestive tract of the animal results in the mineral dietary requirement (Coelho da Silva, 1995).

This work aimed at determining requirements of macro minerals by Zebu steers grazing Brachiaria decumbens Stapf under supplementation with concentrate.

\section{Material and Methods}

The experiment was carried out in Setor de Bovinocultura de Corte in Departamento de Zootecnia at Universidade Federal de Viçosa, from July $4^{\text {th }} 2005$ to April $6^{\text {th }} 2006$.

It was used 24 non-castrated Zebu steers at initial age of 7 months and weight of $180 \mathrm{~kg}$. Those animals were slaughtered following a slaughter protocol divided in four steps aiming at determining body composition and empty body weight at different ages and body weight (BW) ranges.
Body composition obtained in each slaughter was used to estimate initial body composition of the animals in immediately subsequent slaughters.

After the start of the experiment, on July $14^{\text {th }} 2005$, in the middle of the dry season, two animals at 7 months of age and $180 \mathrm{~kg}$ were slaughtered; at the second slaughter, performed on October $10^{\text {th }} 2005$, at the beginning of dry-rainy period transition phase, three animals at 9 months of age and $190 \mathrm{~kg}$ were slaughtered; and at the third slaughter, carried out on January $10^{\text {th }} 2006$ during the wet season, three other animals at 15 months of age and $305 \mathrm{~kg}$ were slaughtered.

During slaughters, all the constituents of the body (organs, guts, blood, leather, head, and members) were weighted and sampled for determination of empty body weight (EBW) and body composition of the animals in different weight ranges.

Data concerned to the third slaughter were used to estimate initial body composition in sixteen of the animals that remained in the experiment.

The 16 remaining animals were at 14 months of age on average and $316 \mathrm{~kg}$ of body weight, and they were divided into four four-plot animals, following a complete random block design. Each plot was supplemented with mineral mixture or supplement at the levels $0.75 ; 1.50$ or $2.25 \mathrm{~kg} /$ animal/day.

The supplement given at different quantities presented $33 \%$ of crude protein (Table 1 ) and the mineral mix (47.15\% sodium chloride - $\mathrm{NaCl}, 50 \%$ dicalcium phosphate, $1.5 \%$ zinc sulfate, $0.75 \%$ copper sulfate, $0.05 \%$ cobalt sulphate, $0.05 \%$ potassium iodated and $0.5 \%$ magnesium sulphate) was ad libitum fed for all the animals.

The experimental area for the animals was made up of four 2.0-ha pickets, formed with Brachiaria decumbens Stapf., provided with covered wooden drinkers and feeders with simultaneous access on both sides. Aiming at reducing influences from possible variation in pasture dry matter availability, animals were kept in each picket for seven days. After that, rotation among pickets was carried out.

All animals were submitted to a grazing digestion trial for a 10-day period, in which the seven first days were

Table 1 - Supplement percentage composition based on natural matter

\begin{tabular}{lc}
\hline Ingredient & $\%$ in the supplement \\
\hline Urea/amonium sulphate $(9: 1)$ & 2.50 \\
Corn & 31.00 \\
Soybean meal & 16.50 \\
Cottonsead meal & 25.00 \\
Wheat meal & 25.00 \\
\hline
\end{tabular}


designed for adaptation of the animals and for stabilization of flow marker as described by Titgemeyer et al. (2001).

To evaluate bromatological composition of the forage consumed by the animals, it was used four esophagusfistulated animals, which, after a 16-hour food and water fast, were conducted to the experimental paddocks for esophageal extrusa collection. Collections were made at 7 a.m. on the fifth digestion trial day, using collecting bags with screen at the bottom, fitted around esophageal fistula. After 40 minutes of grazing, the bags were removed and the samples were weighted.

To estimate fecal dry matter excretion (FE), it was used chromic oxide as external marker, following recommendations by Smith \& Reid (1955), and used in a unique daily dose (10 g/animal) packed in a paper cartridge and introduced using an applicator directly in the esophagus of the animals during nine consecutive days. After seven days of adaptation, it was collected samples of the animal feces on the eighth (16 hours), ninth (12 hours) and tenth (8 hours) days. Calculation of fecal extraction was performed using the ratio between quantity of the supplied indicator and its concentration in the feces, according to the following equation:

\section{$F E=($ Supplied $\mathrm{Cr} /$ Fecal Cr $) \times 100$}

in which: supplied $\mathrm{Cr}$ = quantity of supplied $\mathrm{Cr}(\mathrm{g})$ and fecal $\mathrm{Cr}=$ concentration of the marker in the feces (\%).

Voluntary dry matter intake (DMI) was estimated by using as internal marker indigestible ADF (iADF), obtained after 264-hour in situ incubation (Casali et al., 2008) by the following equation:

$$
\begin{gathered}
D M I=\{[(F E \times i A D F \text { Feces })-i A D F \text { Supplem ent }] \div \\
\text { iADF Forrage }\}+D M I S
\end{gathered}
$$

in which: iADF present in the feces; iADF present in the supplement; iADF present in the forage $(\mathrm{kg} / \mathrm{kg})$ and DMIS = dry matter intake of supplement $(\mathrm{kg} /$ day $)$.

For determination of individual dry matter intake of supplement (DMIS), it was used titanium dioxide at the average quantity $10 \mathrm{~g} /$ animal, mixed to the supplement right before supply, following procedure described by Valadares Filho et al. (2006b), following the same fecal collection scheme described for chromic oxide, following the equation:

$$
\text { DMIS }=(\text { FE } \times \text { Fecal TiO }) \div \text { Supplement TiO }
$$

in which: fecal $\mathrm{TiO}$ and supplement $\mathrm{TiO}$ refers to titanium dioxide concentration in the feces and in the supplement, respectively.

After collection, samples of extrusa and feces were dried in a forced air ventilation oven at $65^{\circ} \mathrm{C}$ for 72 hours, processed in Willey-type mill ( $1.00 \mathrm{~mm}$ ) and then submitted to laboratorial analyses according to the techniques described by Silva \& Queiroz (2002) except for NDF and ADF determinations, which followed methods described by Mertens (2002) and Van Soest \& Robertson (1985).

The last slaughter was carried out on March 27th 2006, March $29^{\text {th }} 2006$ and on April $5^{\text {th }} 2006$ in staggered way after 76, 78, 83 and 85 days, when it was slaughtered four animals per turn, one from each treatment. At the slaughter, animals were at 17 months of age and at $378 \mathrm{~kg} \mathrm{BW}$.

Before slaughtering, all animals were fasted (solid and liquid) for 16 hours to obtain shrunk body weight (SBW).

The gastrointestinal tract of each animal was weighted, emptied and washed as well, and its weight were added up to the organs and other parts of the body (carcass, head, leather, tail, feet and blood) for determination of empty body weight (EBW). The obtained ratio between empty body weight and body weight of the animals, in each slaughter, was used to estimate empty body weight of the animals that remained in the experiment. Within each treatment, two animals were raffled to represent them. It was withdrawn samples from their heads and from one former member and one posterior member for physical separation of soft tissue, bones and leather.

Blood samples were collected immediately after jugular veins of the animals were sectioned. They were packed in glass containers and left in a forced air ventilation oven at $60^{\circ} \mathrm{C}$ for 72 hours. Samples of industrial meat, liver, heart, kidneys, spleen, lungs, tongue, rumen, reticule, omasum, abomasum, small intestine, large intestine, mesentery, internal fat, trimmings and tail were grouped, processed and completely homogenized in a 65-L cutter, from where it was withdrawn a sample that represented the organs and the guts.

Carcass of each animal was divided in two halves, which were weighted and then cooled in a cooled chamber at $-2.5^{\circ} \mathrm{C}$ for approximately 18 hours. After that, the right carcass of eight animals, two per treatment, were removed from the cold chamber and totally dissected and then separated into muscles, fat and bones, which were later weighted. Body composition of other eight animals was estimated through percentages of muscles, fat and bones from dissected carcasses.

Muscle and adipose tissues were ground and bone tissue was sawed into smaller parts. A representative sample of each component was removed. After the fresh parts were ground, they were processed following procedure described by Paulino et al. (2004), for obtainment of fatty dry matter and then defatted dry matter. After that, samples were processed in a ball mill for posterior quantifications of macromineral contents (calcium, phosphorus, magnesium, 
sodium and potassium) according to recommendations by Silva \& Queiroz (2002).

Mineral solution for determination of mineral macroelements was prepared through a wet via. After appropriate dilutions, content of phosphorus was determined through colorimetry, contents of calcium and magnesium were determined using atomic absorption spectrophotometer and contents of sodium and potassium were determined using a flame spectrophotometer.

By using data concerned to initial, intermediate and final slaughter, it was possible to calculate contents of mineral macroelements withheld in the body of the animals in different body weight ranges, through logarithm regression equation of content of calcium, phosphorus, magnesium, sodium or potassium in function of EBW logarithm, according to ARC (1980), following the model:

$$
Y=a+b x+e_{i j}
$$

in which: $\mathrm{Y}=$ logarithm of the total content of the total inorganic macroelement withheld in the empty body; a = constant; $b$ = regression coefficient of logarithm of the inorganic macroelement content in function of EBW logarithm; $\mathrm{X}=\mathrm{EBW}$ logarithm and $\mathrm{e}_{\mathrm{ij}}$ = random error.

By deriving prediction equations of the body contents, it was obtained the net requirements of macrominerals $(\mathrm{Ca}$, $\mathrm{P}, \mathrm{Mg}, \mathrm{K}$ e $\mathrm{Na}$ ) per kg of empty body gain (EBG), from the following equation:

$$
Y^{\prime}=\text { b. } 10^{a} \cdot X^{b-1}
$$

in which: $Y^{\prime}$ = inorganic macroelement requirements; a and $\mathrm{b}=$ intercept and regression coefficient, respectively of equations of prediction of net requirement of mineral macronutrients; and X = EBW (kg).

To estimate maintenance requirements of each mineral macroelement and, afterwards, adding them to gain requirement to obtain total dietary requirements, they were fitted according to recommendations by ARC (1980) and by NRC (2000) for endogenous losses of calcium, phosphorus, magnesium, sodium and potassium and bioavailability from these elements in the food, according to ARC (1980) and NRC (2000) (Table 2).

\section{Results and Discussion}

The ratio obtained for estimate of empty body weight from body weight of the animals in the present work was: $\mathrm{EBW}=\mathrm{BW} \times 0.8997$, a value close to that suggested by NRC (2000), 0.891 and by BR-Corte (Valadares Filho et al., 2006a), 0.8960, although those relationships had been obtained for feedlot animals.

When the relationships obtained in this work are compared to those available on grazing animals, it is observed that data from this work are superior to those found by Zervoudakis et al. (2002), Fregadolli (2005) and Moraes et al. (2010), who reported values of 85.75; 87.46; and 88.77 respectively, for grazing animals.

To convert requirements for EBG into requirements for body weight gain (BWG), it was obtained the following relationship: $\mathrm{EBG}=0.930 \times \mathrm{BWG}$, almost the same of that recommended by Valadares Filho et al. (2006a) of 0.933.

\begin{tabular}{|c|c|c|}
\hline Element & Total endogenous & Bioavailibility (\%) \\
\hline Calcium & $15.4 \mathrm{mg} / \mathrm{kg} \mathrm{BW} \mathrm{BW}^{1}$ & $50^{1}$ \\
\hline Phosphorus & $16.0 \mathrm{mg} / \mathrm{kg} \mathrm{BW}{ }^{1}$ & $68^{1}$ \\
\hline Magnesium & $3.0 \mathrm{mg} / \mathrm{kg} \mathrm{BW}^{1}$ & $17^{2}$ \\
\hline \multirow[t]{2}{*}{ Sodium } & $6.8 \mathrm{mg} / \mathrm{kg} \mathrm{BW} \mathrm{BW}^{1}$ & $91^{2}$ \\
\hline & Feces - $2.6 \mathrm{~g} / \mathrm{kg}$ DM consumed ${ }^{2}$ & \\
\hline \multirow[t]{3}{*}{ Potassium } & Urine $-37.5 \mathrm{mg} / \mathrm{kg} \mathrm{BW}^{2}$ & \\
\hline & Saliva $-0.7 \mathrm{~g} / 100 \mathrm{~kg} \mathrm{BW}^{2}$ & \\
\hline & Through skin - 1.1 g/day ${ }^{2}$ & $100^{2}$ \\
\hline
\end{tabular}

Table 2 - Total endogenous losses and bioavailability of macrominerals in the food

${ }^{1}$ Data obtained from NRC (2000); ${ }^{2}$ Data obtained from ARC (1980).

Table 3 - Parameters of regression equations of logarithm of content of macrominerals in the empty body in function of logarithm of

\begin{tabular}{|c|c|c|c|}
\hline \multirow[t]{2}{*}{ Macromineral } & \multicolumn{2}{|c|}{ Parameters } & \multirow[t]{2}{*}{$r^{2}$} \\
\hline & Intercept (a) & Coeficient (b) & \\
\hline Calcium & -0.9922 & 0.6876 & 0.80 \\
\hline Phosphorus & -1.3989 & 0.7168 & 0.85 \\
\hline Magnesium & -3.6365 & 0.9173 & 0.92 \\
\hline Sodium & -2.7918 & 1.0319 & 0.97 \\
\hline Potassium & -2.8869 & 1.0437 & 0.97 \\
\hline
\end{tabular}
empty body weight of beef cattle under grazing

$\mathrm{EBW}=\mathrm{BW} \times 0.8997$. 
Table 4 - Net requirements of macrominerals by beef cattle under pasture supplementation

\begin{tabular}{|c|c|c|c|c|c|}
\hline \multirow[t]{2}{*}{ Body weight (kg) } & \multicolumn{5}{|c|}{ Net requirement (g per kg of empty body weight gain) } \\
\hline & Calcium & Phosphorus & Magnesium & Sodium & Potassium \\
\hline 150 & 15.127 & 7.132 & 0.141 & 1.949 & 1.678 \\
\hline 250 & 12.896 & 6.171 & 0.135 & 1.981 & 1.716 \\
\hline 300 & 12.182 & 5.861 & 0.133 & 1.992 & 1.729 \\
\hline 350 & 11.609 & 5.610 & 0.132 & 2.002 & 1.741 \\
\hline
\end{tabular}

$\mathrm{EBW}=\mathrm{BW} \times 0.8997$

Determination coefficients $\left(\mathrm{r}^{2}\right)$ of regression equations of the logarithm of contents of calcium, phosphorus, magnesium, sodium and potassium in the empty body, in function of empty body weight $(\mathrm{kg})$, overall, showed good adjustment of the equation to the data (Table 3).

As body weight of the animals increased, it was observed that net requirement of minerals was reduced, except for sodium and potassium (Table 4). Reduction of requirements of calcium, phosphorus and magnesium is in agreement to many reports in literature, among them, the ones by Fontes (1995), in analysis with many works; Paulino et al. (1999), when working with Zebu cattle; and Ferreira et al. (1998), with F1 Simmental $\times$ Nellore steers.

It is reported in AFRC (1991) a reduction in calcium and phosphorus body concentrations per kilogram of gain when body weight increased. This could be explained by the increase in body fat content, which had been previously discussed, and the concomitant reduction in bone proportion with increase of weight and age of the animals. Reduction in bone proportion in the body of the animal induces a fall of the concentrations of calcium and phosphorus inasmuch as bones contain around $99 \%$ and $80 \%$ of body calcium and phosphorus, respectively.

Calcium net requirements for an animal with $400 \mathrm{~kg} \mathrm{BW}$ were $11.13 \mathrm{~g}$, a value which was close to $11.95 \mathrm{~g}$ reported by BR-Corte (Valadares Filho et al., 2006a) for the same body weight. Phosphorus net requirements for an animal with $400 \mathrm{~kg}$ (5.40 g) were close to those reported by Fontes (1995), $6.87 \mathrm{~g}$ for non-castrated animals, by BR-CORTE, $6.30 \mathrm{~g}$ and by Ferreira et al. (1998), 4.37g.

By using the AFRC (1991) mathematical model, for a bovine with $400 \mathrm{~kg} \mathrm{BW}$, and taking into account weight at maturity of $500 \mathrm{~kg}$, net requirement per kilogram of estimate gains for calcium and phosphorus are 10.3 and $6.1 \mathrm{~g}$, respectively.

Magnesium net requirements ( $\mathrm{g} / \mathrm{kg}$ of EBW), verified in the present work $(0.130 \mathrm{~g})$ were much lower than the value granted by BR-Corte (Valadares Filho et al., 2006a), which was $0.340 \mathrm{~g}$ and those found in most of the national literature, as for example works by Véras et al. (2001), 0.210 g;
Ferreira et al. (1998), 0.280 g; Silva et al. (2002), 0.320 g; Paulino et al. (1999), $0.227 \mathrm{~g}$, and by Paulino et al. (2004), 0.250 g. In addition, it is stated in ARC (1980) a constant magnesium net requirement of $0.45 \mathrm{~g} / \mathrm{kg}$ of EBW, regardless to weight of the animal, a value much superior to the one found in this study.

Contrary to the behavior showed by most of the published works on mineral requirements by beef cattle in Brazil, net requirement of sodium and potassium increased when body weight of the animals increased. It was not found in the consulted literature, biological explanations for this behavior. Because variations in the requirements of these minerals are low, ARC (1980) advocates established net requirements of sodium and potassium of 1.50 and $2.0 \mathrm{~g} / \mathrm{kg}$ of empty body weight.

The net requirement found in the present work for animals with body weight of 250 and $400 \mathrm{~kg}$ were, respectively, 1.98 and $2.01 \mathrm{~g} / \mathrm{kg}$ of EBG for sodium and 1.72 and $1.75 \mathrm{~g} / \mathrm{kg}$ of EBG for potassium. Fontes (1995) estimated potassium net requirements ranging from 1.76 to 1.87 per $\mathrm{kg}$ of EBW for non castrated animals and body weight from 300 to $500 \mathrm{~kg}$.

From average coefficients of real absorption suggested by NRC (2000) for calcium and phosphorus and by ARC (1980) for magnesium, potassium and sodium (Table 2) and from estimates of net requirement for gain (Table 3), it was estimated dietary requirements of calcium, phosphorus, magnesium, sodium and potassium, per kg of empty body weight (Table 5). By applying the factor 0.93 found in this work, it could be calculated net requirement for body weight gain (BWG).

For determination of dry matter intake (DMI) of the animals in this experiment, in a determined body weight and range of weight gain, it was generated the following equation from experimental data:

$\mathrm{DMI}(\mathrm{kg} /$ day $)=-1.80+0.0113 \mathrm{BW}+6.40 \mathrm{BWG}-1.15 \mathrm{BWG}^{2}$

$$
\left(\mathrm{R}^{2}=0.83\right)
$$

Based in this equation and taking as example an animal with $350 \mathrm{~kg} \mathrm{BW}$, gaining $1.0 \mathrm{~kg} /$ day, there is a dry matter 
Table 5 - Dietary requirements of macrominerals for weight gain of beef cattle under pasture supplementation

\begin{tabular}{|c|c|c|c|c|c|}
\hline \multirow[t]{2}{*}{ Body weight (kg) } & \multicolumn{5}{|c|}{ Dietary requirement for weight gain (empty body weight gain g/kg) } \\
\hline & Calcium & Phosphorus & Magnesium & Sodium & Potassium \\
\hline 150 & 30.25 & 10.49 & 0.83 & 2.14 & 1.68 \\
\hline 200 & 27.65 & 9.67 & 0.81 & 2.16 & 1.70 \\
\hline 250 & 25.79 & 9.08 & 0.80 & 2.18 & 1.72 \\
\hline 300 & 24.36 & 8.62 & 0.78 & 2.19 & 1.73 \\
\hline 350 & 23.22 & 8.25 & 0.77 & 2.20 & 1.74 \\
\hline 400 & 22.27 & 7.94 & 0.77 & 2.21 & 1.75 \\
\hline
\end{tabular}

$\mathrm{EBW}=\mathrm{BW} \times 0.8997 ; \mathrm{EBG}=\mathrm{BWG} \times 0.93$.

Table 6 - Total dietary requirements (maintenance $+1.0 \mathrm{~kg}$ gain BW) of macrominerals by beef cattle under pasture supplementation

\begin{tabular}{|c|c|c|c|c|c|c|c|c|c|c|}
\hline \multirow[t]{3}{*}{ Body weight $(\mathrm{kg})$} & \multicolumn{10}{|c|}{ Total dietary requirement } \\
\hline & \multicolumn{2}{|c|}{ Calcium } & \multicolumn{2}{|c|}{ Phosphorus } & \multicolumn{2}{|c|}{ Magnesium } & \multicolumn{2}{|c|}{ Sodium } & \multicolumn{2}{|c|}{ Potassium } \\
\hline & g/day & $\% \mathrm{DM}^{1}$ & g/day & $\% \mathrm{DM}$ & g/day & $\% \mathrm{DM}$ & g/day & $\% \mathrm{DM}$ & g/day & $\% \mathrm{DM}$ \\
\hline 150 & 34.87 & 0.68 & 14.02 & 0.27 & 3.48 & 0.07 & 3.28 & 0.06 & 22.74 & 0.44 \\
\hline 200 & 33.81 & 0.59 & 14.37 & 0.25 & 4.34 & 0.08 & 3.67 & 0.06 & 26.42 & 0.46 \\
\hline 250 & 33.49 & 0.53 & 14.96 & 0.24 & 5.21 & 0.08 & 4.05 & 0.06 & 30.09 & 0.48 \\
\hline 300 & 33.60 & 0.49 & 15.68 & 0.23 & 6.08 & 0.09 & 4.43 & 0.06 & 33.77 & 0.49 \\
\hline 350 & 34.00 & 0.46 & 16.49 & 0.22 & 6.95 & 0.09 & 4.81 & 0.06 & 37.44 & 0.51 \\
\hline 400 & 34.59 & 0.43 & 17.36 & 0.22 & 7.82 & 0.10 & 5.19 & 0.07 & 41.11 & 0.52 \\
\hline
\end{tabular}

$\mathrm{EBW}=\mathrm{BW} * 0.8997 ;{ }^{1} \mathrm{DMI}(\mathrm{kg} / \mathrm{day})=-1.80+0.0113 \times \mathrm{BW}+6.40 \times \mathrm{BWG}-1.15 \times \mathrm{BWG}^{2}$.

intake of $7.40 \mathrm{~kg} / \mathrm{day}$. Therefore, for animal with $350 \mathrm{~kg}$ body weight gain $1.0 \mathrm{~kg} /$ day, kept in pasture conditions, it is necessary that the total diet presents $0.46 \% \mathrm{Ca}$ and $0.22 \% \mathrm{P}$ in dietary dry matter (Table 6).

Dietary requirements of calcium for weight gain by an animal with body weight 250 or $400 \mathrm{~kg}$ and weight gain of $1.0 \mathrm{~kg} /$ day obtained in this work (25.79 and $22.27 \mathrm{~g}$, respectively), are close to the predicted by NRC (2000), which cites values of 25 and $19 \mathrm{~g} /$ day; to the values reported by BR-Corte (Valadares Filho et al., 2006a), 26.53 and $23.90 \mathrm{~g}$; to the ones by Silva et al. (2002), 23.84 and 21.49 and to the ones the reported by Moraes (2006), 25.95 and $23.09 \mathrm{~g}$, when working with animals under grazing.

Total dietary requirements of phosphorus for weight gain, determined in this experiment for animals at 250 and $400 \mathrm{~kg}$ (9.08 and $7.94 \mathrm{~g}$ ), were very close to the ones recommended by NRC (2000), 10 and $8 \mathrm{~g}$, for variation of body weight cited before. They were also very close to the recommendations by BR-Corte (Valadares Filho et al., 2006a), 10.37 and $9.26 \mathrm{~g}$ and to the values reported by Moraes (2006), with animals under grazing, of 10.24 and 8.68g.

Contrary to what was observed for gain requirements, total dietary requirement raised as body weight of the animals increased (Table 6), inasmuch as maintenance requirements, which are determined according to body weight, are included in total requirement.

Total dietary requirement of calcium and phosphorus for an animal with $400 \mathrm{~kg}$ BW and daily gain of $1.0 \mathrm{~kg}$ were, respectively, 34.59 and 17.36 g/day. NRC (2000) estimate total dietary requirements of $31.0 \mathrm{~g} /$ day for calcium and $18.0 \mathrm{~g} /$ day for phosphorus, respectively, for the animal above described. Additionally, BR-Corte (Valadares Filho et al., 2006a) estimate total dietary requirement of calcium and phosphorus, for the animal at matter, of $400 \mathrm{~kg}$ with weight gain of $1.0 \mathrm{~kg} /$ day, in 36.22 and $18.67 \mathrm{~g} /$ day.

Paulino et al. (2004), in an experiment with Zebu animals, determined total dietary requirement of calcium and phosphorus for a 400-kg animal with weight gain of $1.0 \mathrm{~kg} /$ day and found values very close (33.32 and $16.84 \mathrm{~g} /$ day, respectively) to the ones reported in this work.

Experimental data showed that, for a bovine with $400 \mathrm{~kg} \mathrm{BW}$ and weight gain of $1.0 \mathrm{~kg} /$ day, total dietary requirements of magnesium, sodium and potassium would be 7.82, 5.19 and $41.11 \mathrm{~g}$ /day, respectively (Table 6). According to ARC (1980), for the bovine at matter, total dietary requirements of these nutrients would be 9.50; 4.64 and $43.38 \mathrm{~g} /$ day, respectively. BR-Corte (Valadares Filho et al., 2006a) suggests the values 9.06; 4.26 and $44.42 \mathrm{~g} /$ day as total dietary requirements of magnesium, sodium and potassium for a bovine with $400 \mathrm{~kg} \mathrm{BW}$ gaining $1.0 \mathrm{~kg} /$ day.

For conditions of beef cattle herds raised in Brazil, BRCorte (Valadares Filho et al., 2006a) suggests that total dietary requirements would be $0.41 ; 0.21 ; 0.10 ; 0.05$ and $0.50 \%$ total DM in the diet for calcium, phosphorus, magnesium, sodium and potassium, respectively. The values 
in this study, (Table 6) are very close to the recommendations by BR-Corte (Valadares Filho et al., 2006a) for mineral macroelements in Brazilian conditions.

\section{Conclusions}

Requirements of macrominerals by beef cattle under grazing suplementation are similar to those recomended by BR-Corte for bovines in fedlots.

\section{References}

AGRICULTURAL AND FOOD RESEARCH COUNCIL - AFRC. A reappraisal of the calcium and phosphorus requirements of sheep and cattle. 6.ed. Nutrition Abstract and Reviews (Series B). Wallingford, 1991. p.573-612.

AGRICULTURAL RESEARCH COUNCIL - ARC. The nutrient requirements of ruminants livestock. London: Commonwealth Agricultural Bureaux, 1980. 351p.

CASALI, A.O.; DETMANN, E.; VALADARES FILHO, S.C.V. et al. Influência do tempo de incubação e do tamanho de partículas sobre os teores de compostos indigestíveis em alimentos e fezes bovinas obtidos por procedimentos in situ. Revista Brasileira de Zootecnia, v.37, n.2, p.335-342, 2008.

COELHO DA SILVA, J.F. Exigências de macroelementos inorgânicos para bovinos: o sistema ARC/AFRC e a experiência mo Brasil. In: SIMPÓSIO INTERNACIONAL SOBRE EXIGÊNCIAS NUTRICIONAIS DE RUMINANTES, 1., 1995, Viçosa, MG. Anais... Viçosa, MG: Universidade Federal de Viçosa, 1995. p.467-504.

CONRAD, J.H.; MAcDOWELL, L.R.; ELLIS, G.L. et al. Minerais para ruminantes em pastejo em regiões tropicais. Trad. de Valéria Pacheco Euclides. Campo Grande: EMBRAPA CNPGC, 1985. 90p.

DAYRELL, M.S. Suplementação mineral para vacas de leite de alta produção. In: MINI-SIMPÓSIO DO COLÉGIO BRASILEIRO DE NUTRIÇÃO ANIMAL NUTRIÇÃO E ALIMENTAÇÃO DE GADO LEITEIRO, 9., 1993, Valinhos. Anais... Campinas: CBNA, 1993. p.71-81.

FERREIRA, M.A.; VALADARES FILHO, S.C.; MUNIZ, E.B. et al. Composição corporal e exigências líquidas de macroelementos minerais de bovinos F1 Simental x Nelore. Revista Brasileira de Zootecnia, v.28, n.2, p.361-367, 1998.

FONTES, C.A.A. Composição corporal, exigências líquidas de nutrientes para ganho de peso e desempenho produtivo de animais zebuínos e mestiços europeu-zebu. Resultados experimentais. In: SIMPÓSIO INTERNACIONAL SOBRE EXIGÊNCIAS NUTRICIONAIS DE RUMINANTES, 1., 1995, Viçosa, MG. Anais... Viçosa, MG: Universidade Federal de Viçosa, 1995. p.419-455.

FREGADOLLI, F.L. Composição corporal e exigências nutricionais de novilhos de três grupos genéticos em pastejo. 2005. 85f. Tese (Doutorado em Zootecnia) Universidade Estadual Paulista, Faculdade de Ciências Agrárias e Veterinárias, Jaboticabal.
MERTENS, D.R. Gravimetric determination of amylase treated neutral detergent fiber in feeds with refluxing in beakers or crucibles: collaborative study. Journal of AOAC International, v.85, n.6, p.1212-1240, 2002.

MORAES, E.H.B.K. Desempenho e exigências de energia, proteína e minerais de bovinos de corte em pastejo, submetidos a diferentes estratégias de suplementação. 2006. 151f. Tese (Doutorado em Zootecnia) - Universidade Federal de Viçosa, Viçosa, MG.

MORAES, E.H.B.K.; PAULINO, M.F.; MORAES, K.A.K. et al. Exigências de proteína de bovinos anelorados em pastejo. Revista Brasileira de Zootecnia, v.39, n.3, p.601-607, 2010.

NATIONAL RESEARCH COUNCIL - NRC. Nutrient requirements of beef cattle. 7.rev.ed. National Academic Press. Washington, D.C.: 2000. 242p.

PAULINO, M.F.; FONTES, C.A.A.; JORGE, A.M. et al. Composição corporal e exigências de energia e proteína para ganho de peso de bovinos de quatro raças zebuínas. Revista Brasileira de Zootecnia, v.28, n.3, p.627-633, 1999.

PAULINO, P.V.R; COSTA, M.A.L.; VALADARES FILHO, S.C. et al. Exigências nutricionais de zebuínos. Energia. Revista Brasileira de Zootecnia, v.33, n.3, p.781-791, 2004.

SILVA, D.J; QUEIROZ, A.C. Análise de alimentos (métodos químicos e biológicos). 3.ed. Viçosa, MG: Universidade Federal de Viçosa, 2002. 235p.

SILVA, F.F.; VALADARES FILHO, S.C.; ÍTAVO, L.C.V. et al. Composição corporal e requisitos líquidos e dietéticos de macroelementos minerais debovinos nelore não castrados. Revista Brasileira de Zootecnia, v.31, n.2, p.757-764, 2002.

SMITH, A.M.; REID, J.T. Use of chromic oxide as an indicator of fecal output for the purpose of determining the intake of a pasture herbage by grazing cows. Journal of Dairy Science, v.38, n.5, p.515-524, 1955.

TITGEMEYER, E.C.; ARMENDARIZ, C. K.; BINDEL, D.J. et al. Evaluation of titanium dioxide as a digestibility marker for cattle. Journal of Animal Science, v.79, p.1059-1063, 2001.

VALADARES FILHO, S.C.; PAULINO, P.V.R.; DETMANN, E. et al. Exigências nutricionais de zebuínos no Brasil. I. Energia. In: VALADARES FILHO; S.C.; PAULINO; P.V.R.; MAGALHÃES; K.A. (Orgs.). Exigências nutricionais de zebuínos e tabelas de composição de alimentos. BR-Corte. São Geraldo: Suprema Gráfica Ltda., 2006a. p.57-73.

VALADARES FILHO, S.C.; MORAES, E.H.B.K.; DETMANN, E. et al. Perspectivas do uso de indicadores para estimar o consumo individual de bovinos alimentados em grupo. In: Reunião Anual da Sociedade Brasileira de Zootecnia, 43., 2006, João Pessoa. Anais... João Pessoa: SBZ; UFPB, 2006b. p.291-322.

VAN SOEST, P.J.; ROBERTSON, J.B. Analysis of forages and fibrous foods. Ithaca: Cornell University, 1985. 202p.

VÉRAS, A.S.C.; VALADARES FILHO, S.C.; SILVA, J.F.C. et al. Composição corporal e requisitos líquidos e dietéticos de macroelementos minerais de bovinos Nelore não-castrados. Revista Brasileira de Zootecnia, v.30, n.3, p.1106-1111, 2001.

ZERVOUDAKIS, J.T.; PAULINO, M.F.; DETMANN, E. et al. Conteúdo corporal e exigências líquidas de proteína e energia de novilhos suplementados no período das águas. Revista Brasileira de Zootecnia, v.31, n.1, p.530-537, 2002. 